\title{
A STUDY ON STRENGTH PROPERTIES OF CONCRETE CONTAINING MICRO-SILICA AND NANO- SILICA
}

\author{
P. Thasleem ${ }^{1}$, K. Naveen Kumar ${ }^{2}$ \\ ${ }^{\text {I}} P G$ Student, Department of Civil Engineering, Shree Institute of Technical Education, Tirupati, Andhra Pradesh, \\ India \\ ${ }^{2}$ Assistant Professor, Department of Civil Engineering, Shree Institute of Technical Education, Tirupati, Andhra \\ Pradesh, India.
}

\begin{abstract}
This paper presents an experimental investigation on the influence of Nano-Silica (NS) on various strength characteristics of concrete containing Micro-Silica (MS). Micro-Silica and Nano-Silica are used as partial replacement of cement for the preparation of concrete. In the present investigation cement is partially replaced by $5 \%$ and $10 \%$ of Micro-Silica and $1.5 \%$ and $3 \%$ of Nano-Silica by weight. The combined application of Micro-Silica and Nano-Silica on various properties of M30 and M40 grades of concrete is investigated. The various properties of concrete under investigation include the compressive strength, split tensile strength and flexural strength. The test results of M30 and M40 grades of concrete prepared using different proportions of Micro-Silica and Nano-Silica are compared with that of controlled concrete. Based on the test results, concrete prepared with a combination of 10\% Micro-Silica and 1.5\% Nano-Silica possesses improved strength properties compared to the controlled concrete.
\end{abstract}

Keywords: Micro-Silica, Nano-Silica, Particle Packing, Combination and Strength of Concrete.

$* * *$

\section{INTRODUCTION}

Concrete is the most commonly used material in various types of construction, from the flooring of a hut to a high rise structure, from pathway to an airport runway, from an underground tunnel and deep sea platform to high-rise chimneys and TV Towers. The construction industry uses concrete to a very large extent. Cement is one of the important components of concrete. The cement industry produces about $5 \%$ of global man-made $\mathrm{CO} 2$ emissions, of which $50 \%$ is from the chemical process, and $40 \%$ from burning fuel. Hence, to reduce the consumption of cement, the application of Pozzolana materials is increasing day-byday in the form of partial cement replacement for concrete preparation. Previous studies indicated that the use of microsilica leads to the reduction in cement consumption and also helps to increase the strength and durability of concrete (Mazloom et al 2004 and Bhanaja and Sengupta 2002).

The modern concrete construction industry uses nano materials as supplementary materials to improve the performance of concrete. Recent developments in Nanotechnology and the availability of nano-silica find its applications in concrete. Due to the smaller particles size and high surface area compared to the micro-silica, the use of nano-silica enhances the compressive strength of concrete more effectively than micro-silica. Hence, the influence of combined application of micro-silica and nano-silica in concrete preparation needs to be investigated.

\section{OBJECTIVE}

The main objective of the present experimental investigation is to obtain the influence of the combined application of micro-silica and nano-silica on various strength properties of M30 and M40 grades of concrete. 5\% and 10\% of MicroSilica and $1.5 \%$ and $3 \%$ of Nano-Silica by weight of cement replacement is adopted. Compressive strength, split tensile strength and flexural strength of the two grades of concrete prepared using different proportions nano-silica and microsilica are to be obtained and the results are to be compared with that of controlled concrete.

\section{EXPERIMENTAL INVESTIGATION}

\subsection{Properties of Materials}

\subsection{Cement}

In the present investigation Ordinary Portland Cement (OPC) of 43 Grade confirming to IS specifications was used. The properties of cement are shown in Table.1.

Table1. Properties of Cement

\begin{tabular}{|l|l|l|}
\hline S.No & Property & Value \\
\hline 1 & Specific Gravity & 3.13 \\
\hline 2 & Normal Consistency & $32 \%$ \\
\hline \multirow{3}{*}{3} & Setting Time & \\
& a) Initial Setting time & $120 \mathrm{Min}$ \\
& b) Final setting time & 6 hours \\
\hline
\end{tabular}

\subsection{Fine Aggregate}

Locally available river sand confirming to IS specifications was used as the fine aggregate in the concrete preparation. The properties of fine aggregate are shown in Table.2. 
Table2. Properties of Fine Aggregate

\begin{tabular}{|l|l|l|}
\hline S.No & Property & Value \\
\hline 1 & Specific Gravity & 2.69 \\
\hline 2 & Fineness Modulus & 2.9 \\
\hline 3 & Bulk Density (Loose) & $15.75 \mathrm{kN} / \mathrm{m}^{3}$ \\
\hline 4 & Grading of Sand & Zone - II \\
\hline
\end{tabular}

\subsection{Coarse Aggregate}

Crushed granite metal of nominal size $20 \mathrm{~mm}$ and $10 \mathrm{~mm}$ obtained from the local quarry and confirming to IS specifications were used. The properties of coarse aggregate are shown in Table.3. The coarse aggregate used for the preparation of concrete is a combination of $20 \mathrm{~mm}$ and 10 $\mathrm{mm}$ size aggregates in ratio $1.5: 1.0$

Table3. Properties of Coarse Aggregate

\begin{tabular}{|l|l|l|}
\hline S.No & Property & Result \\
\hline 1 & Specific Gravity & 2.60 \\
\hline 2 & Bulk Density (Loose ) & $14.13 \mathrm{kN} / \mathrm{m}^{3}$ \\
\hline 3 & Water Absorption & $0.4 \%$ \\
\hline 4 & Fineness Modulus & 7.2 \\
\hline
\end{tabular}

\subsection{Micro-Silica}

Micro-Silica is very fine non-crystalline silica, produced in electric arc furnaces as a by-product of the production of elemental silicon or alloys containing silicon. The typical particle size is less than $1 \mu \mathrm{m}$, hence can be considered as an excellent material fills the space between the cement particles. Micro-silica can also be considered as a supplementary cementitious material. In this experimental investigation, $5 \%$ and $10 \%$ of micro-silica was used as cement replacement by weight. The properties of MicroSilica are shown in Table 4

Table4. Properties of Micro - Silica

\begin{tabular}{|l|l|l|}
\hline S.No. & Property & Value \\
\hline 1 & $\mathrm{SiO}_{2}$ & $90.20 \%$ \\
\hline 2 & Moisture & $0.20 \%$ \\
\hline
\end{tabular}

\begin{tabular}{|l|l|l|}
\hline 3 & Pozzolana Activity Index & $127 \%$ \\
\hline 4 & Specific Surface Area & $21 \mathrm{~m}^{2} / \mathrm{gm}$ \\
\hline 5 & $>45$ Microns & $0.20 \%$ \\
\hline
\end{tabular}

\subsection{Nano-Silica:}

Nano-Silica is a new pozzolanic material in the form of water emulsion of colloidal silica. It appears to be potentially better than micro-silica because of higher content of amorphous silica $(>99 \%)$ and the reduced size of its spherical particles $(1-50 \mathrm{~nm})$. In this experimental investigation cement is replaced by $1.5 \%$ and $3 \%$ of nanosilica by weight. The properties of nano-silica are shown in Table 5 .

Table.5. Properties of Nano-silica

\begin{tabular}{|l|l|l|}
\hline S.No. & Property & Actual Analysis \\
\hline 1 & Nano solids & $39.5-41 \%$ \\
\hline 2 & PH & $9-10$ \\
\hline 3 & Specific Gravity & $1.29-1.31$ \\
\hline 4 & Texture & Milky White Liquid \\
\hline 5 & Dispersion & Water \\
\hline
\end{tabular}

\subsection{Water}

Water used for casting and curing of concrete test specimens is free from impurities which when present can adversely influence the various properties of concrete.

\subsection{Super Plasticizer}

Super plasticizer (Glenium-D) is used to achieve the required workability. The dosage of super plasticizer is $1 \%$ by weight of cement in case of concrete prepared with only micro-silica and $2 \%$ by weight of cement for the concrete prepared with micro-silica and nano-silica combination.

\subsection{Concrete Mix Proportion}

In the present experimental investigation the influence of combined application of micro-silica and nano-silica as partial replacement of cement on M30 and M40 grades of concrete is studied.

Table.6 (a) Quantities of Ingredients per cum of M30 Grade Concrete

\begin{tabular}{|l|l|l|l|l|}
\hline Concrete & $\begin{array}{l}\text { Cement } \\
(\mathrm{kg})\end{array}$ & $\begin{array}{l}\text { Micro-Silica } \\
(\mathrm{kg})\end{array}$ & $\begin{array}{l}\text { Colloidal Nano-Silica } \\
(\text { Lit })\end{array}$ & $\begin{array}{l}\text { Water } \\
(\text { lit })\end{array}$ \\
\hline Control & 350 & 0 & 0 & 140 \\
\hline MS 5\% & 332 & 18 & 0 & 140 \\
\hline MS 10\% & 315 & 35 & 0 & 140 \\
\hline MS 5\%+NS 1.5 $\%$ & 326.7 & 18 & 5.25 & 136.85 \\
\hline MS 10\%+NS 1.5 $\%$ & 309.7 & 35 & 5.25 & 136.85 \\
\hline MS 5\%+NS 3 $\%$ & 321.5 & 18 & 10.5 & 133.7 \\
\hline MS 10\%+NS 3 $\%$ & 304.5 & 35 & 10.5 & 133.7 \\
\hline
\end{tabular}


M30 and M40 grades of concrete were designed as per the Indian Standard code of practice. The various ingredients for one cubic meter of M30 and M40 grades concrete are shown in Table 6 (a) and Table 6 (b). As the Nano-silica is available in the colloidal form, the quantity of water required for making concrete is adjusted to account for the water available in colloidal Nano-silica. The quantities of fine aggregates are $725 \mathrm{kgs}$ and coarse aggregates of 1246 $\mathrm{kgs}$ per cum of M30 grade concrete with a water cement ratio of 0.40 . For M40 grade of concrete the quantities of fine aggregates are $625 \mathrm{kgs}$ and coarse aggregates of 1210 kgs are adopted.

Table.6 (b) Quantities of Ingredients per cum of M40 Grade Concrete

\begin{tabular}{|l|l|l|l|l|}
\hline Concrete & $\begin{array}{l}\text { Cement } \\
(\mathrm{kg})\end{array}$ & $\begin{array}{l}\text { Micro-Silica } \\
(\mathrm{kg})\end{array}$ & $\begin{array}{l}\text { Colloidal Nano-Silica } \\
(\text { lit })\end{array}$ & $\begin{array}{l}\text { Water } \\
(\text { lit })\end{array}$ \\
\hline Control & 380 & 0 & 0 & 152 \\
\hline MS 5\% & 361 & 19 & 0 & 152 \\
\hline MS 10\% & 342 & 38 & 0 & 152 \\
\hline MS 5\%+ NS 1.5 \% & 355.3 & 19 & 14.25 & 143.45 \\
\hline MS 10\%+ NS 1.5 \% & 336.3 & 38 & 14.25 & 143.45 \\
\hline MS 5\%+NS 3 \% & 349.6 & 19 & 28.5 & 134.9 \\
\hline MS 10\%+ NS 3 $\%$ & 330 & 38 & 28.5 & 134.9 \\
\hline
\end{tabular}

\section{3test Specimens}

Concrete test specimens consist of $150 \mathrm{~mm} \times 150 \mathrm{~mm} \times 150$ $\mathrm{mm}$ cubes, cylinders of $150 \mathrm{~mm}$ diameter and $300 \mathrm{~mm}$ height and $100 \mathrm{~mm} \times 100 \mathrm{~mm} \times 500 \mathrm{~mm}$ prisms. Concrete cube specimens were tested at 3, 7, 28 and 56 days of curing to obtain the compressive strength of concrete. Cylindrical specimens were tested at the age of 28 days to obtain the compressive strength and split tensile strength of concrete. The prisms were tested at the age of 28 days to obtain the flexural strength of concrete. The rate of loading is as per the Indian Standard specifications.

\section{RESULTS AND DISCUSSIONS}

\section{1 compressive Strength}

The variation of the cube compressive strength with the age of M30 and M40 grades concrete prepared using the various proportions of micro-silica and nano-silica is shown in Fig.1. Each value of the cube compressive strength indicates the average of three test results. It can be observed that the compressive strength of nano-silica concrete exhibits more than the control concrete up to $1.5 \%$ of nano-silica and with further increase in nano-silica the strength decreases for the given micro-silica content. Similar trend is observed in the two grades of concrete M30 and M40.

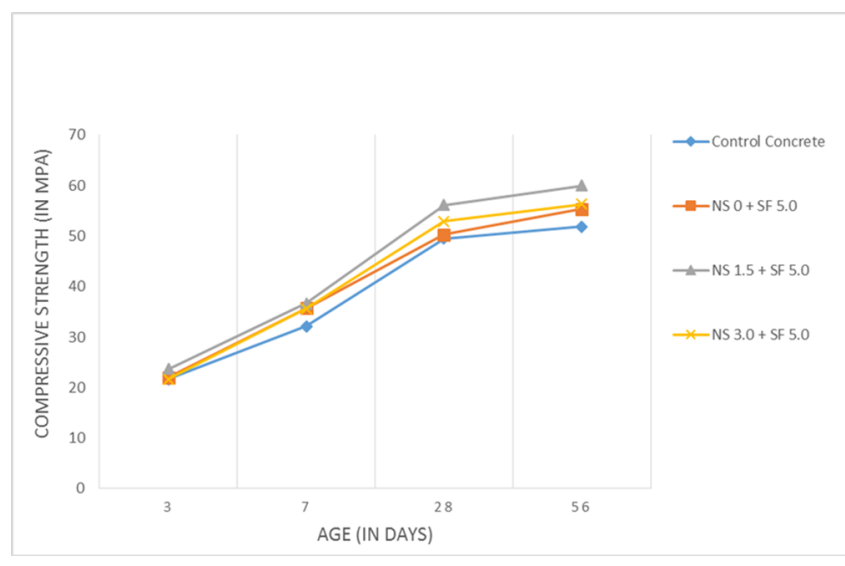

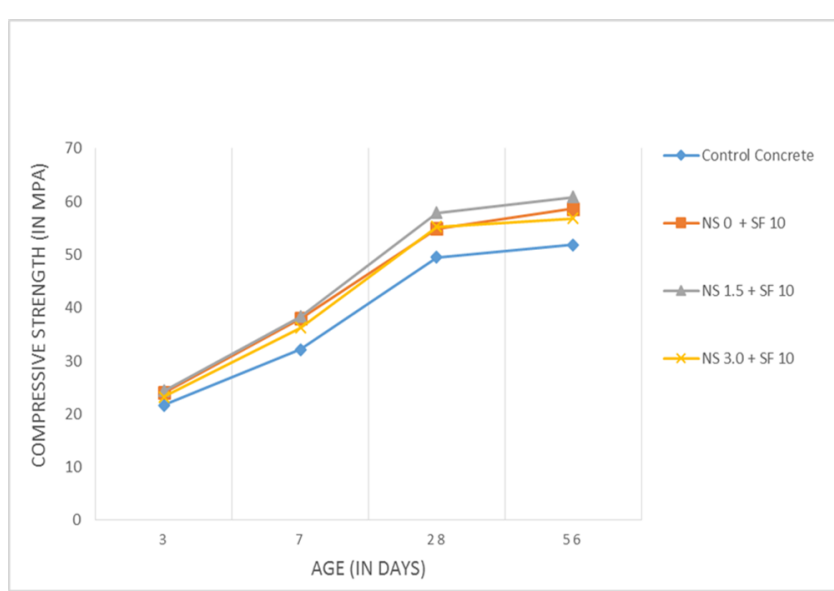

(i) $5 \%$ Micro-Silica

(ii) $10 \%$ Micro-Silica

Fig. 1(a). Variation of Cube Compressive Strength of M40 Grade Concrete with age for different percentages of Micro-silica and Nano-Silica. 


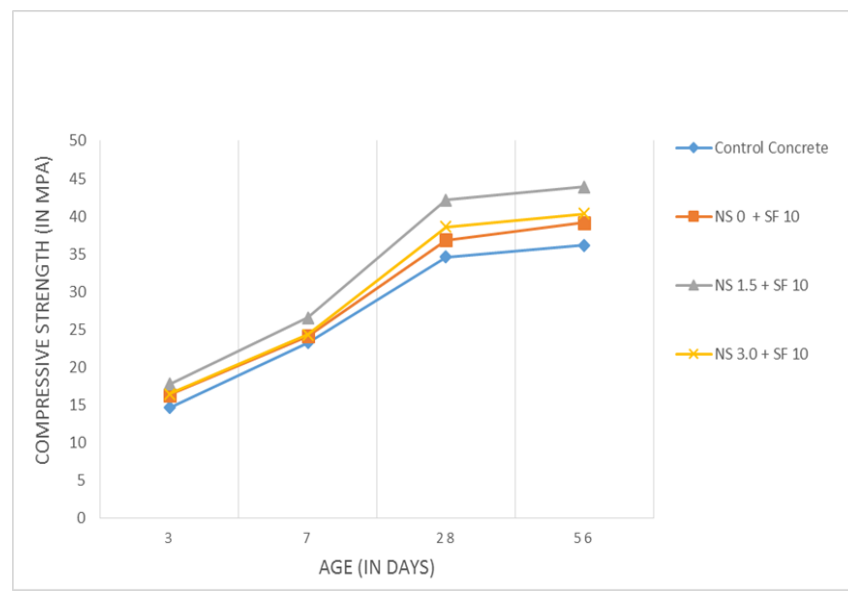

(i) $5 \%$ Micro Silica

(ii) $10 \%$ Micro Silica

Fig. 1(b). Variation of Cube Compressive Strength of M30 Grade Concrete with age for different percentages of Micro-silica and Nano-Silica.

The variation of 7 days and 28 days cube compressive strength of M30 and M40 grades of concrete prepared with nano-silica containing different percentages of micro-silica is also shown in Fig.2 (a) \& 2(b). The compressive strength of concrete initially increases up to $1.5 \%$ nano-silica and then the strength decreased with increase in nano-silica for $5 \%$ and $10 \%$ micro-silica.
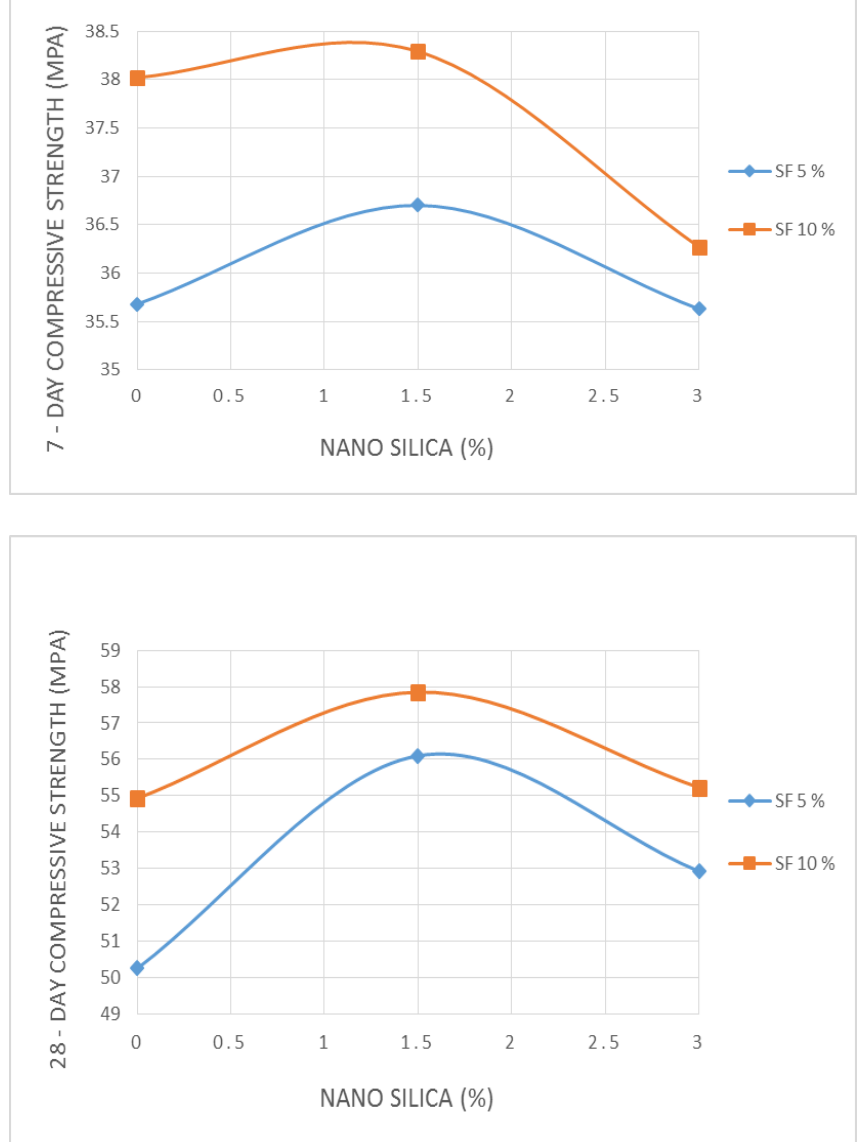

(a) 7 days Cube Compressive Strength

(b) 28 days Cube Compressive Strength
Fig. 2 (a) Variation of 7 days and 28 days Cube Compressive Strength of M40 Grade of Concrete with different percentages of Micro-Silica and Nano-Silica

The 7 days and 28 days cube compressive strength of M40 grade control concrete is $32.10 \mathrm{~N} / \mathrm{mm}^{2}$ and $49.49 \mathrm{~N} / \mathrm{mm}^{2}$ respectively. The increase in 7 days and 28 days cube compressive strength concrete with $1.5 \%$ nano-silica and $10 \%$ micro-silica combination is $18.44 \%$ and $16.89 \%$ respectively.
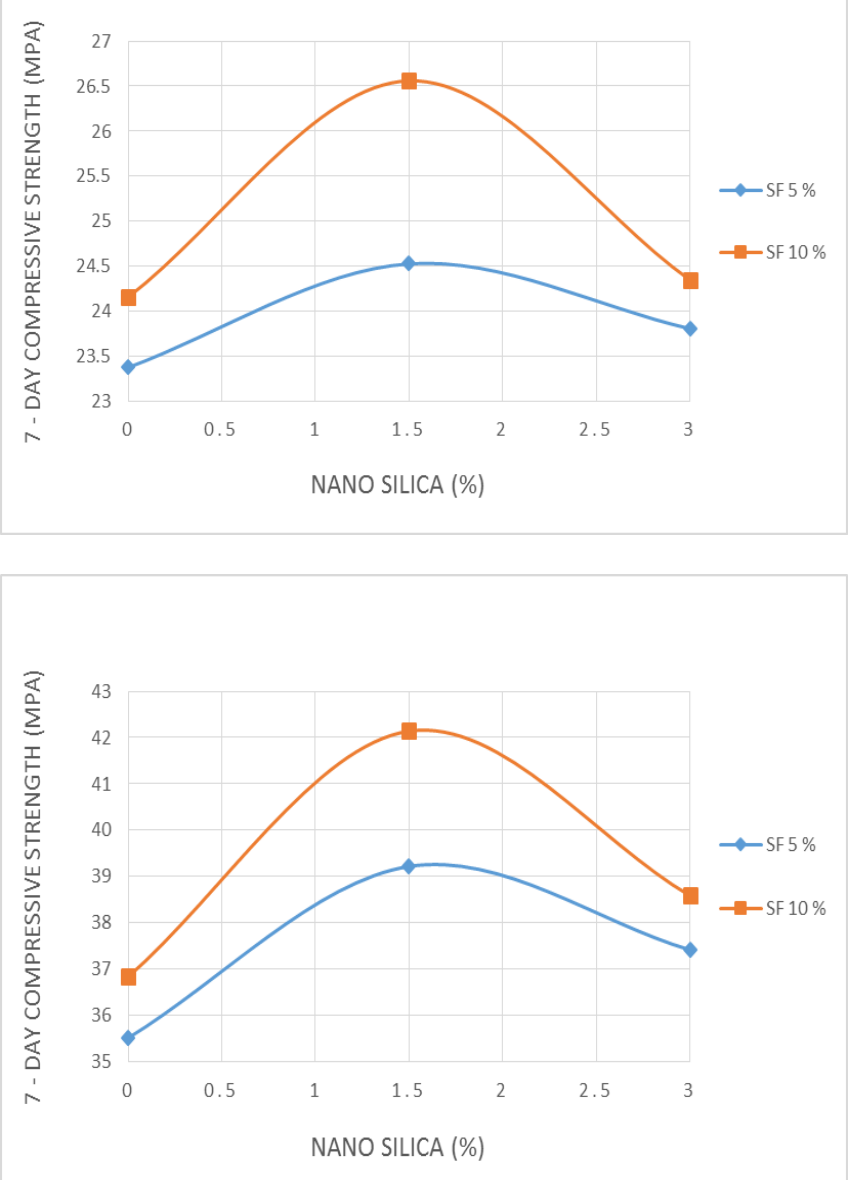

(a) 7 days Cube Compressive Strength

(b) 28 days Cube Compressive Strength

Fig. 2 (a) Variation of 7 days and 28 days Cube Compressive Strength of M30 Grade of Concrete with different percentages of Micro-Silica and Nano-Silica

The 7 days and 28 days cube compressive strength of M30 grade control concrete is $23.29 \mathrm{~N} / \mathrm{mm}^{2}$ and $34.60 \mathrm{~N} / \mathrm{mm}^{2}$ respectively. The increase in 7 days and 28 days cube compressive strength concrete with $1.5 \%$ nano-silica and $10 \%$ micro-silica combination is $14.04 \%$ and $21.80 \%$ respectively.

Comparison is also made between the 28 days cube compressive strength and cylindrical compressive strength of concrete containing various percentages of micro-silica and nano-silica. 
The test results are shown in Table 7 . The ratio of cube strength to the cylinder strength is found to be around 0.95 for concrete containing micro-silica and nano-silica.

Table: 7(a) \& 7(b). Comparison Between 28 days Cube and Cylinder Compressive Strength of Concrete Prepared with MicroSilica (MS) and Nano-Silica (NS)

\begin{tabular}{|c|c|c|c|c|}
\hline \multirow[b]{2}{*}{ S.No. } & \multirow[b]{2}{*}{ Concrete } & \multicolumn{3}{|l|}{ M30 Grade } \\
\hline & & $\begin{array}{l}\text { Cube Compressive Strength } \\
\left(\mathrm{N} / \mathrm{mm}^{2}\right) \\
\sigma_{\text {Cube }}\end{array}$ & $\begin{array}{l}\text { Cylinder Compressive } \\
\text { Strength }\left(\mathrm{N} / \mathrm{mm}^{2}\right) \\
\sigma_{\text {Cylinder }}\end{array}$ & $\sigma_{\text {Cylinder }} / \sigma_{\text {Cube }}$ \\
\hline 1 & Controlled & 34.60 & 32.04 & 0.93 \\
\hline 2 & MS 5\% & 35.52 & 34.30 & 0.97 \\
\hline 3 & MS 10\% & 36.84 & 35.58 & 0.97 \\
\hline 4 & MS $5 \%+$ NS $1.5 \%$ & 39.22 & 36.90 & 0.94 \\
\hline 5 & MS $10 \%+$ NS $1.5 \%$ & 42.14 & 40.02 & 0.95 \\
\hline 6 & MS $5 \%+$ NS $3 \%$ & 37.42 & 36.12 & 0.97 \\
\hline 7 & MS $10 \%+$ NS $3 \%$ & 38.59 & 36.80 & 0.95 \\
\hline
\end{tabular}

\begin{tabular}{|l|l|l|l|l|}
\hline \multirow{2}{*}{ S.No. } & \multirow{2}{*}{ Concrete } & \multicolumn{2}{|l|}{ M40 Grade } \\
\cline { 3 - 5 } & & $\begin{array}{l}\text { Cube Compressive Strength } \\
\left(\mathrm{N} / \mathrm{mm}^{2}\right) \quad \sigma_{\text {Cube }}\end{array}$ & $\begin{array}{l}\text { Cylinder Compressive } \\
\text { Strength }\left(\mathrm{N} / \mathrm{mm}^{2}\right) \sigma_{\text {Cylinder }}\end{array}$ & $\sigma_{\text {Cylinder }} / \sigma_{\text {Cube }}$ \\
\hline 1 & Controlled & 49.49 & 44.23 & 0.89 \\
\hline 2 & MS 5\% & 50.26 & 48.97 & 0.97 \\
\hline 3 & MS 10\% & 54.93 & 52.07 & 0.95 \\
\hline 4 & MS 5\%+NS 1.5\% & 56.1 & 52.83 & 0.94 \\
\hline 5 & MS10\%+NS 1.5\% & 57.85 & 56.26 & 0.97 \\
\hline 6 & MS 5\%+NS 3\% & 52.93 & 50.27 & 0.95 \\
\hline 7 & MS 10\%+NS 3\% & 55.23 & 51.33 & 0.93 \\
\hline
\end{tabular}

\section{2split Tensile Strength}

The variation of split tensile strength of M30 and M40 grades of concrete with increase in Nano-silica is shown in Fig. 3. The split tensile strength of M30 and M40 grades of control concrete is $2.72 \mathrm{~N} / \mathrm{mm}^{2}$ and $4.06 \mathrm{~N} / \mathrm{mm}^{2}$ respectively.

The split tensile strength of concrete initially increases up to $1.5 \%$ of Nano-silica and with further increase in the nanosilica content the split tensile strength decreases. Similar trend can be observed with the concrete containing 5\% and $10 \%$ Micro-silica. The increase in the split tensile strength of M30 and M40 grades of concrete with 1.5\% nano-silica and $10 \%$ micro-silica combination is $13.05 \%$ and $15.44 \%$ respectively.

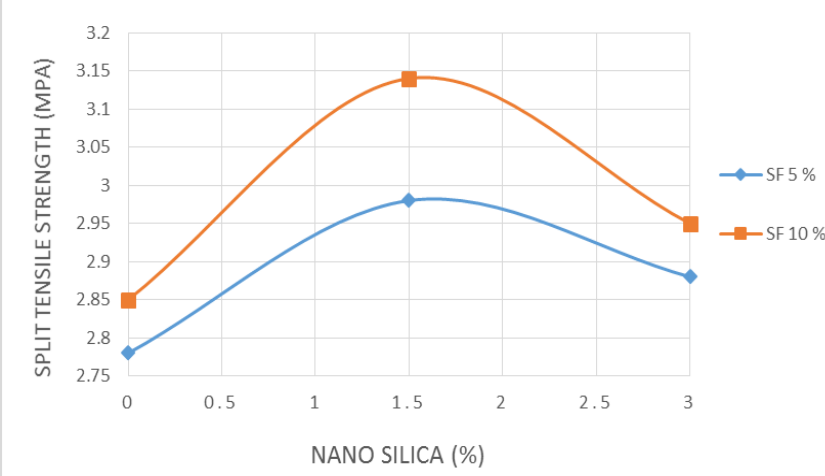

Fig.3 .Variation of Split Tensile Strength of M30 and M40 Grades of Concrete with different percentages of MicroSilica and Nano-Silica. 


\subsection{Flexural Strength}

The variation of flexural strength of M30 and M40 grades of concrete containing various proportions of micro-silica and nano-silica is shown in Fig.4. The flexural strength of M30 and M40 grades of control concrete is $4.40 \mathrm{~N} / \mathrm{mm}^{2}$ and 6.46 $\mathrm{N} / \mathrm{mm}^{2}$ respectively. The flexural strength of concrete initially increases up to $1.5 \%$ percentage of Nano-Silica and then with further increase in the Nano-Silica the flexural strength decreases for different percentage of Micro-Silica content. The increase in the flexural strength of M30 and M40 grades of concrete with $1.5 \%$ nano-silica and $10 \%$ micro-silica combination is $17.5 \%$ and $17.49 \%$ respectively.
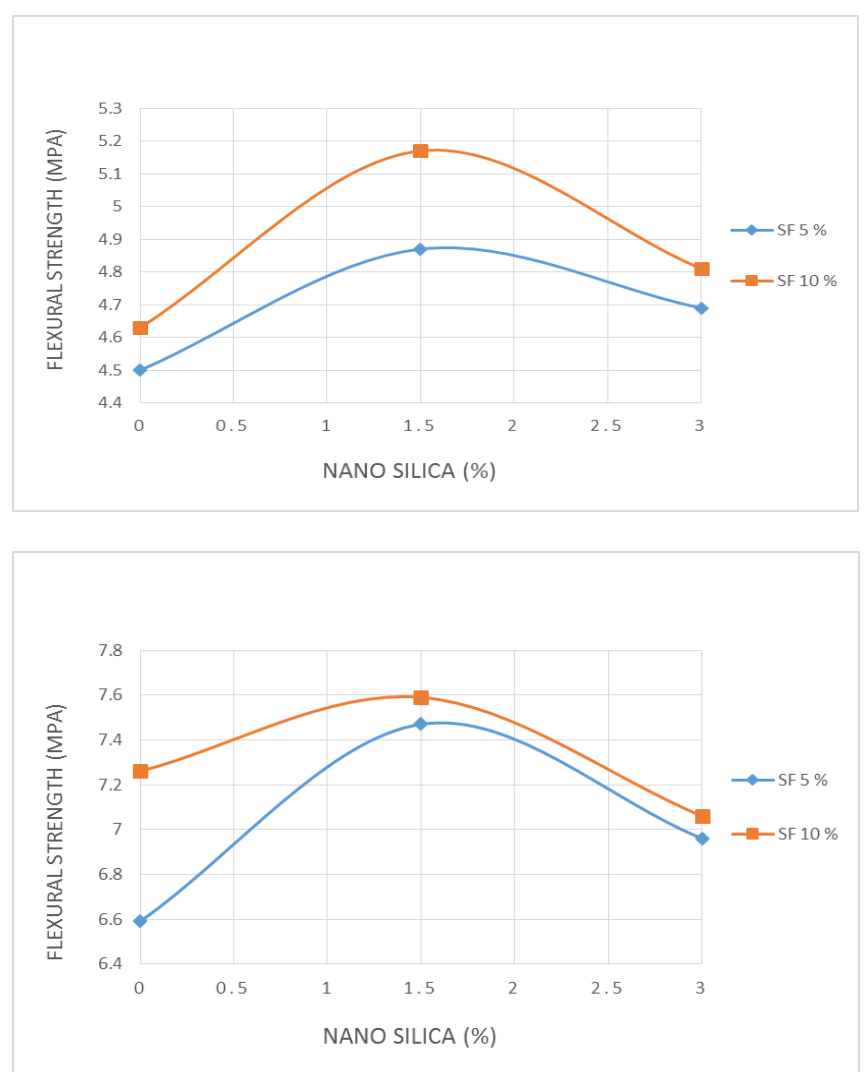

Fig.4 .Variation of Flexural Strength of M30 and M40 Grades of Concrete with different percentages of MicroSilica and Nano-Silica.

\section{CONCLUSIONS}

Using the results of the experimental investigation, it can be concluded that with the increase in the percentage of nanosilica the various strength characteristics of concrete are increased up to $1.5 \%$, with further increase in the nano-silica the strength of concrete is decreased for various percentages of micro-silica. The split tensile strength and flexural strength of M30 and M40 grades of concrete also indicated the similar trend.

The increase in the strength of concrete containing microsilica and nano-silica can be the result of availability of additional binder in the presence of nano-silica and microsilica. Nano-silica has high amorphous silicon dioxide content and is a very reactive pozzolana material. During the hydration of cement along with $\mathrm{CSH}$ gel, calcium hydroxide will also be formed. The nano-silica and micro-silica reacts with the calcium hydroxide to form additional binder. The availability of additional binder improves the pasteaggregate bond and results in the increase in strength characteristics of concrete with nano silica and micro-silica. The decrease in the strength properties of concrete is due to the poor quality of binder in the presence of high percentage of micro-silica and nano-silica.

Based on the experimental investigation the strength properties of concrete can be improved by the addition of $1.5 \%$ of nano-silica and $10 \%$ of micro-silica by weight of cement. Hence, it can be concluded that the cement content can be reduced for the preparation of concrete by the use of nano-silica and micro-silica as cement replacement and considerable percentage increase in various strength properties of concrete can be obtained.

\section{REFERENCES}

[1]. Dr. D.V. Prasada Rao, U. Anil Kumar (2014) “An Experimental Investigation on Strength Properties of Concrete Containing Silica-Fume and Nano-Silica" International Journal of Advanced Research in Engineering \& Technology (IJARET), Volume 5, Issue 6, pp. $193-203$

[2]. Belkowitz, J. and Armentrout, D. L. (2009). "The investigation of Nano silica in the cement hydration process". ACI Special Publication 267(8): 87-100.

[3]. Buil, M., Paillère, A. M. and Roussel, B. (1984). High strength mortars containing condensed silica fume. Cement and Concrete Research 14(5): 693-704.

[4]. Chandra, S. and Berntsson, L. (1996). Use of silica fume in concrete. In: Chandra, S., editor. Waste Materials Used in Concrete Manufacturing. Westwood, NJ: William Andrew Publishing: 554-623.

[5]. Mullick.A.K (2007)."Performance of with Binary cement blends" The Indian Concrete Journal, January.

[6]. Surenra P. Shah, et al. "Controlling b Properties of Concrete through Nano Technology" (ACBM Centre, North Western University, USA), Proc. of the International Conference on advances in Concrete, ICIACECON 2010, 5-9 Dec., IIT, Madras, India, PP 1-8.

[7]. N. Neelamegam, J.K. Dattatreya and S. Goplakrishna "Pore structure effects in properties of concrete with Binary and Ternary Blends" International Conference in Advances in Concrete Composites and Structures, 83-90.

[8]. Abdul Wahab, B. Dean Kumar, M. Bhaskar, S Vijaya Kumar, B.L.P. Swami "Concrete Composites With Nano Silica, Condensed Silica Fume And Fly Ash Study of Strength Properties"

[9]. IS: 8112:1989. 43 Grade Ordinary Portland Cement Specifications. Bureau of Indian Standards, New Delhi.

[10].IS: 383:1970 (Reaffirmed 1997) Specification for Coarse and Fine Aggregates from Natural Sources for Concrete. Bureau of Indian Standards, New Delhi.

[11].IS: 10262-2009. Concrete Mix Proportioning Guidelines (First Revision). Bureau of Indian Standards, New Delhi. 